\title{
ABUSE NATURE AND FACE THE CONSEQUENCES: CLIMATE CHANGE FROM AN ISLAMIC PERSPECTIVE
}

\author{
Rafiu Ibrahim Adebayo*
}

\begin{abstract}
Nature and the environment can be considered from a variety of perspectives. In the pre-Islamic period, for instance, nature was held so sacred that it was worshipped. Today, nature appears to be exclusively subjected to man's benefits through modern technological and scientific discoveries. The disturbance of the natural environment has resulted in various natural disasters. Some scholars consider those catastrophic effects 'man-made' while others believe they are 'natural'. Whatever the case may be, man's excessive penetration into nature has also greatly resulted in climate change. This article shall delve into discusses the various means through which man exploits nature and the extent of the reaction of nature to the exploitation. Adopting a textual analytical approach, the author concludes that as long as human technological muscles are exerted on nature, man must be ready to face its 'wrath' and that anything which in its own way 'worships' God should not be unjustifiably exploited. Man should be conscious of his excessive materialistic urges.
\end{abstract}

\section{Introduction}

Climate change has emerged as yet another threat to human existence in recent times. It occurs due to the changes in the total amount of the sun's energy absorbed by the earth's atmosphere and surface and when there is a change in the amount of heat energy from the earth's surface and atmosphere that escapes to space over an extended period of time. ${ }^{1}$ The widespread prediction of catastrophic climate change is seen as being more critical than global warming. While the former implies general shifts in climate, including temperature, precipitation, winds, and other factors, the latter refers specifically to any change in the global average surface temperature. ${ }^{2}$ Another important thing to note about climate change is the divergences in the views of environmentalists and scientists. Environmentalists see climate change as a consequence of the seemingly limitless emission of gases and other toxic residues. In conjunction with some UN agencies and NGOs, they have succeeded in making their influence felt at the Rio Earth Summit and UN Framework Convention on Climate

* R. Ibrahim Adebayo is a Lecturer in the Department of Religions at the University of Ilorin, Ilorin, Nigeria. 
Change of 1992. This later led to the Kyoto Protocol of December 1997 where specific reductions in $\mathrm{CO}_{2}$-emissions by industrialised nations by 2012 were agreed upon, while the decision to establish a supra-national inspectorate was made with Bonn to serve as the headquarters with the purpose of policing the decarbonisation programme. ${ }^{3}$ To the Lavoisier Group - after the founder of modern chemistry, Antoine-Laurent Lavoisier (d. 1794), "the debate about increasing atmosphere concentrations of carbon dioxide, and the widespread predictions of catastrophic global warming" as claimed by the environmentalists lacks empirical evidence and it is full of scientific implausibility. Ray Evans, a member of this group, considers the careers of some prominent scientists who preach the 'gospel' of anthropogenic carbon dioxide-generated global warming to have been made in a shadowy world where science and politics intersect. ${ }^{4}$ He attributed the unnecessary proclamations on climate change to the influence of such science-politicians as Lord May and James Hansen within the British Government and the media. He then came up with nine facts about climate change to refute the unscientific predictions of global warming among which are that the twentieth century was almost as warm as the centuries of the medieval period, that increasing atmospheric concentrations of carbon dioxide will have negligible impact on the earth's radiation balance and that decarbonisation of the world's economy would, if attempted, cause huge economic dislocation. ${ }^{5}$

In whichever manner this issue is viewed, climate change has assumed an international dimension while legal response to it commenced consequently upon the 1972 World Conference on Human Environment held in Stockholm with 112 countries in attendance. The conference led to the birth of the UN Environmental Programme. In June 1992, the United Nations Conference on Environment and Development (UNCED) met in Rio de Janeiro. The conference was significant in the sense that it culminated in the signing of some documents such as the conventions on climate changes and on biological diversity. ${ }^{6}$

This article shall discuss climate change from the perspective of Islam. To do this, an attempt will be made to discuss nature among different civilisations, but with particular reference to Africa. This will afford us the opportunity of appraising the influence of Islam on preservation of nature and as well as prepare the ground for us to determine whether change in climate is natural or human-caused. To do this successfully, however, a textual analysis approach will be adopted after which a conclusion would be drawn based on the available materials while recommendations will be made for further enhancement of climate that is conducive for human living and other living creatures from the perspective of Islam. 


\section{Nature among Different Civilisations: The African Example}

Right from the inception of man, the importance attached to nature had been great, since most human needs are derived from it. Therefore, nature was everything to man. His prosperity and adversity were both traced to it. For this reason, natural objects became the objects of worship and adoration. Ancient civilisations like the Canaanites, Hittites, Egyptians, and Mesopotamians feared, adored and worshipped physical objects. ${ }^{7}$ In Africa, the story is no different-natural objects are used as symbols of African divinities. In Yorubaland, Nigeria, for instance, the Esu divinity is symbolised by a stone slab or a piece of rough laterite stuck into the ground slantingly. Many other divinities are attached to natural objects like rivers and mountains. Osun is the goddess of river Osun which flows through some towns in Osun State, though actively worshipped in Osogbo the capital city of the state; Oya is the goddess of River Niger and is worshipped in many parts of Yorubaland. Among the Akan and Ga of Ghana, there is Tano, otherwise called Ta Kora, who is regarded as the father of the water gods and is worshipped far and wide with some taboos attached to it. For instance, any ninth child and menstruating women are not allowed near the river. ${ }^{8}$ Apart from this, there are some other divinities which are worshipped for the purpose of protecting nature and such divinities are believed to be the manifestation of the wrath of God which descends on polluters of nature and environment. Amadioha, Ogiuwu and Sango are examples of these divinities in Igbo, Edo and Yoruba lands of Nigeria respectively. They are gods of thunder and lightening and they punish people guilty of perjury and misconducts. There are also Sonponna and Ojukwu who are gods of smallpox in Yoruba and Igbo lands respectively. ${ }^{9}$

Barau $^{10}$ documents the human-nature relationship in some civilisations and cultures. For instance, Buddhism preaches respect for all life forms and restrains the killing of animals and the destruction of plants, which is similar to the concept of Ahimsa in Hinduism. ${ }^{11}$ With particular reference to Nigeria, the Ogun and Osun States in south-western Nigeria are named after two important rivers in the area. Barau further observes that the country derives its name from the River Niger just like its northern neighbour, Niger, while the names of some of the states in the federation are named after important rivers and some environmental features. He writes:

Of the Nigeria's 36 states, six are named after the River Niger, which starts from the Fouta Jallon Plateau in the Republic of Guinea [...]. The states that are named after this important river are Kogi, Kwara, Niger, Rivers, Cross Rivers, and Delta. The first two mean river in Hausa language. Still in Nigeria, some other states are named after some environmental features for instance Jigawa means sand deposition in Hausa, Yobe is the name of a river, and Plateau State is named after the Jos plateau. ${ }^{12}$ 
Apart from rivers, Africans generally use natural phenomena like groves, lakes, rocks, mountains, forest, trees and waterfalls for their religious activities. There, sacrifices, rituals and offerings were made to divinities which they believed were residing in them. The belief in the efficacy of prayers offered at these natural objects could be appreciated in the name given to their children who were believed to have been offered to them through their spiritual contacts with them. For instance, a child believed to have been given through the Osun divinity is given the name Osunbunmi - 'Osun has given me'; while a child begotten through a mountain is given Okeseyi - 'Oke (Mountain) has done this'.

Biblical records contain information on the usefulness of natural resources to mankind. With particular reference to mountainous environment in the Bible, Ojebode $^{13}$ identified the usage of mountains in the Old and New Testaments. From all biblical indications, mountains are places of worship: upon Mount Sinai, the Ten Commandments were given to Moses; upon a mountain the temptation events of Jesus Christ took place where the sermon which heralded the Ministry of Jesus took place, on the Mount of Olives his Transfiguration took place, and at the foot of the mountain of the Gethsemane garden, his pre-trial took place. Biblical accounts also reveal that key events of the life of Elijah took place on Mount Carmel. ${ }^{14}$ Among the Christians in Nigeria, mountains have become so important that various retreat exercises take place on them. Oke Maria in Otan Ayegbaju, Osun State, is a popular mountainous annual pilgrimage centre for Christians in the area and beyond. The sum-total of all this is that nature hosts many other living things apart from human beings, and therefore man cannot see nature as his exclusive property which he can use indiscriminately.

\section{Understanding the Islamic Attitude toward Nature}

Prior to the creation of Adam, nature was already in place. The essence of this was to prepare everything needed for the sustainability of human beings on earth. Natural objects were also used as instruments of examination for the angels and the newly created being - Adam. The identification of these objects by Adam gave him a special position and acknowledgement by the angels. ${ }^{15}$ The objects were thereafter subjected to him. The Sabaeans from Harran made Giza their annual sacred place to where pilgrimage was made because of their belief that the pyramids on the Giza plateau near Cairo were the mazārs of Prophets Idrīs and Seth. The she-camel of the prophet Șaalih was said to have emerged from a rock, while the Ark of Noah was also said to have come to rest on Mount Judi in lower Iraq and that Noah was buried nearby. The cave of the prophet Lot is located just above the eastern edge of the Dead Sea. Some traditions also refer to this cave as the burial place of Lot. The Qur'ān (51:3334) equally mentions stones of clay marked by God which were caused to rain down upon the people of Lot as punishment for their sins. 
The Qur'ān contains many verses that discuss the use of nature by some prophets. For instance, the Prophet Abraham (Ibrāhīm) used the Meccan valley enclosed by hills on all sides as a means of protecting his offspring - Ishmael (Ismā ${ }^{-} 1$ l)--who he dropped off there with his mother in spite of his knowledge that the place was not cultivatable (Qur'ān 14:37). The historic movement of Hagar, Ishmael's mother within the hills of al-Șafā and al-Marwah has now become an important pillar of hajj rites, while the water that gushed out of the ground for little Ishmael is now the Zamzam well used for numerous purposes by Muslims. The Prophet Moses (Mūsā) also received his spiritual message while on a mountain. The Hirā' cave is also significant in Islam since it was the place where Prophet Muhammad received his first call to prophethood. On his way to Medina, he and his friend, Abū Bakr were reported to have stayed in the Thawr cave for three days. The uniqueness of Mount 'Arafât cannot also be overemphasised in Islam, and its importance as a major hajj obligation cannot be underestimated. In Islamic history, 'Ali b. Abī Tāalib was said to have met to adjudicate an end of their armed conflict over the right to the caliphate at a mountain located in the southern area near Mu'tah in today's Hashemite Kingdom of Jordan.

The Qur'ān further testifies to the use of nature against mankind as disciplinary chastisement. In summary form it mentions the nature of the chastisement thus: "Each of them We seized for its crime. Of them, against some We sent a violent tornado (with showers of stones), some were caught by a (mighty) blast, some We caused the ground to swallow, and some We drowned. God did not injure (or oppress) them. They injured (and oppressed) their own souls" (29:40). Expatiating further on the nature of the crimes committed by these nations and the nature of punishment meted on them, Solihu writes:

The Qur'ān recounts some catastrophic chastisements inflicted upon previous nations that violated the moral law. Pharaoh and his soldiers were drowned after violating the "life" value by maltreating and exploiting the Jewish people and killing their first-born sons... Prophet Lot's people violated the "progeny" value by their sodomy. As they valued all vice as virtue and a perverse, shameful act as a hallmark of maturity and pride, they were chastised with a rain of stones and their cities were turned upside down [...]. Prophet Noah's people violated the 'intellect' value when they irrationalised all rational things and associated him and his followers with insanity. Thus, they were wiped out by a flood [...]. Prophet Shu'ayb's people, the Madianites, violated the 'property' value by committing themselves to economic corruption. Thus, they were punished with an earthquake accompanied by a devastating blast $[\ldots] .^{17}$

Apart from this, the Qur'ān refers to nature as containing signs of God. A verse of the Qur'ān (2:164) reads: 
Behold! In the creation of the heavens and the earth; in the alternation of the night and the day; in the sailing of the ships through the ocean for the profit of mankind; in the rain which God sends down from the skies; in the life which He gives therewith to an earth that is dead; in the beasts of all kinds that He scatters through the earth; in the change of the winds; and the clouds which they trail like their slaves between the sky and the earth - (Here) indeed are signs for a people that are wise.

Apart from the qur'ānic assertion that God is the creator of nature, the Qur'ān further asserts that everything in nature worships God because their existence depends on Him and therefore nature should not be worshipped. The Qur'ān (22:18) says: "Seest thou not that to God prostrate all things that are in the heavens and on earth - the sun, the moon, the stars; the hills, the trees, the animals; and a great number among mankind? [...]" The Qur'ān (41:37) further informs: "Among His signs are the Night and the Day, and the Sun and the Moon. Prostrate not to the sun and the moon, but prostrate to God who created them, if it is Him you wish to serve."

Another important thing to note here is the structure of nature as created by God. Without mincing words, the Qur'ān calls for proper scrutiny of His creation of nature by human beings and assures that they would not observe any flaw therein. In short, the well-defined parameters of the planets, moons, stars, galaxies and that of the universe and general interconnectivity of the chain of beings is properly elucidated in the following passage of the Qur'ān (67:3-4):

He who created the seven heavens one above another; no want of proportion will thou see in the creation of the Most Gracious. So turn your vision again, seest thou any flaw? Again turn your vision a second time; thy vision will come back to you dull and discomfited, in a state worn out.

Commenting on the above qur'ānic verses, Solihu expresses the proportions and the general interconnectivity of the chain of the planets and other creatures in the following attractive words:

If too close, too frequent, or too late, life on the planet would be exterminated by radiation; if too far, too frequent, or too soon, not enough heavy elements would exist for the formation of rocky planets. Likewise, if the gravitational force constant were larger, stars would be too hot and would burn up quickly and unevenly; if smaller, they would remain too cool for nuclear heavy elements. ${ }^{18}$

Speaking in the same vein, Akhtaruddin and his colleagues discuss the perfection in the work of the Creator as regard the planets in the solar system. They make some yet to be confirmed hypotheses namely the likelihood of having more than nine planets and the probability of other "bigger suns and stars in the universe round [which] it is suggested other planets and moons move." They then conclude: 
As the sun travels through space - a vast void - it takes all its planets and asteroids with it orbiting in a fixed order constrained by gravity. Solar gravity keeps the planets in their orbits. For millions of years an order has been meticulously maintained by a force superior to tiny man, and superior even to the earth and the vast stars [...]. The nearest planets - Mercury (58 million km away) - and the farthest - Pluto (5,930 million km away) - and the other seven planets and all their moons and asteroids move round the sun in a faultless dynamic balance. ${ }^{19}$

The orderliness in the creations of God could also be appreciated in the functions of the sun in the universe. Apart from giving us light, it at the same time keeps us warm. Its closeness to us would have been disastrous, while its non-existence would have made life difficult to live. The earth is also proportionately sited to the sun so that it is neither too close to nor too distant from the sun. Its closeness to the sun would have made it inhabitable to living things because of heat, while its distance from the sun would have made the glaciers cover it and so few living things would have been able to survive. Harun Yahya also expresses the mercy of God in surrounding our planet with a protective shield which prevents meteors from falling on earth. According to him, meteors are stones that break off from planets or the remnants of material from stars and go about in space and from time to time fall on the surfaces of planets causing them great damage. ${ }^{20}$ In his words, he discusses the workability of this, thus:

When meteors fall on other planets, they create giant craters, but when they fall on earth, they don't cause much harm. So how do meteors cause great damage to the surfaces of other planets, but not to the surface of earth? The reason for this is the atmosphere that surrounds earth. The atmosphere encircles our planets as a protective shield. A meteor entering the atmosphere shrinks through combustion. When it comes closer to the surface of earth, it becomes even smaller. Therefore, the meteor becomes very small or even diminishes and disappears completely by the time it reaches the surface of the earth, and causes us no harm.

The atmosphere doesn't only prevent harm from meteors, but it also absorbs harmful rays that come from the sun. Yet again, if these harmful rays were able to reach earth's surface, it would have been impossible for living things to survive. ${ }^{21}$

Apart from the sun, the Qur'ān mentions the proportionate nature of rain sent by God to perform multi-purpose functions for mankind. It says: "And We sent down water from the sky according to (due) measure, and We cause it to soak in the soil; and We certainly are able to drain it off (with ease)" (23:18). Expounding on this verse, the late Abdullah Yusuf Ali wrote:

Normally the rain comes well distributed; it soaks into the soil; moisture is retained for a long time in all high grounds; it soaks and penetrates through many layers of 
soil and forms the architecture of physical geography; the retentive powers of higher soil enable rivers to flow perennially even where, as in India, the rainfall is seasonal and confined to a few months in the year. Another form in which water comes down from [the] sky according to due measure is in snow and hail: these also have their place in the economy of air and soil. Were it not for snow and glaciers in the higher mountain regions, some of the rivers would fail in their abundant flow. As wonderful as the supply of water and moisture is its drainage. It returns to the sea and air in all sorts of ways, and the formation of mist and clouds repeats the cycle. Were it not for the drainage and the clearance of the waters, we would have floods and waterlogging, as happens when the normal processes of nature are temporarily obstructed. The same thing happens when the rain comes down in other than due measure. These abnormal conditions also have their value. ${ }^{22}$

There is also wisdom in God's creating oceans over 70 percent of the earth. This is so to perform the role of climate control. The oceans and the atmosphere work harmoniously together to exchange heat, water, gases, and momentum in the form of wind and waves, and at the same time work together carrying solar heat away from the Tropics toward the poles for moderation of global temperature. If this is the case, it then implies that any noticeable flaw in nature is man-made and so man will have a taste of such an action that has caused it. Even excessive aesthetic beautification of nature by man is artificial and it has its side effect on him. Urbanisation syndrome has made him to construct high structured palaces, dams, tourist and attractive centres where morality is grossly downplayed. No wonder, the Qur'ān confirms that "mischief has appeared on land and sea because of the evil that the hands of men have earned" and that they will be made to taste part of what they have done. This may possibly make them turn back from their evil deeds (Qur'ān 30:41).

There is every indication that God is in strict control of nature and will not allow it to be hijacked by man. So making man taste of his action could be seen as a means of checking man's excesses. This explains why the effects of radiation and chemical substances consequent upon an atomic bomb dropped on the Japanese city of Hiroshima during the Second World War caused also harm to the survivors, destroying the bodily systems of the exposed and causing their children to be born either sick or crippled. The Ukrainian city of Chernobyl witnessed an explosion of its nuclear plant in 1986 which resulted in radiation that spread over the surrounding areas and even as far as Western Europe and consequently led to many of the inhabitants becoming cripples or even dying from radiation. ${ }^{23}$ Solihu also discusses the enormity of the human violation of nature and that the consequences of his actions could not in any way measure up to the extent of that violation. He emphasises the mercy of God and His forgiveness which is being referred to as nature's resilience. He therefore cites the case of the 2005 haze of smoke triggered by forest fires in Sumatra, Indonesia, which might have affected the respiratory, circulatory, and olfactory systems of millions, 
causing asthma, but which God in His mercy alleviated by sending the wind to clear the air and rain to clean the remaining smoky air. ${ }^{24}$

\section{Climate Change and the Extent of Human interference with Nature}

Both natural and artificial factors have been attributed to changes in global climate. Such natural processes like volcanic eruptions, variations in the sun's intensity, or very slow changes in ocean circulation or land surfaces are changes that can be caused by natural processes. ${ }^{25}$ The release of 'greenhouse gases' and aerosols into the atmosphere and the depleting of the stratospheric ozone layer are some human factors that cause that change. The Industrial Revolution in Europe which precipitated and necessitated expansion in the use of electricity and automobiles and attracted more human personnel marked the first noticeable step to the pollution of land, water, and air. As industries could hardly be effective in the absence of energy, the Industrial Revolution facilitated rapid transformation in the field of transportation and communications. The high consumption of coal, oil, wood, and hay for the generation of power today therefore becomes the source of gases emission and other toxic residues which is a serious threat to clean environment. While combustion of coal results in emissions to the atmosphere of sulphur, carbon and nitrogen oxides, the automobiles release tonnes of carbon monoxide gas in addition to other pollutants generated from industrial oil, gas and atomic power.

The fact still remains that energy resources are vital to human livelihood since they serve as the basis of their developmental activities. As vital as these resources are, undue interference and disturbance of the environment by mankind make them inimical to human sustenance. Through modern technological and scientific discoveries, many useful implements are produced for the benefit of man. Although, these discoveries are beneficial to man, their side effects are enormous. The natural air is grossly polluted by toxic gases which are produced by oil refineries, industrial and agricultural factories, and vehicles like buses, cars, trains, aeroplanes, power boats and air-cooling and refrigeration equipment. With modern science, thousands of chemicals are manufactured to boost human activities in the fields of health, agriculture, defence, industry and other facets of development.

The above points explain why scholars are not unanimous on whether climate change is natural or man-made. Most of them however have largely subscribed to its artificiality. Solihu who does not agree that any disaster is natural holds that natural disturbance might not necessarily be disastrous and that it is only those who are anthropocentrically inclined and regard the world only in terms of human values and experiences that see any natural disturbance as being disastrous. ${ }^{26} \mathrm{He}$ then cites some species and ecosystems that actually depend upon natural disturbances for their continuous existence and vitality and as well adapt to such natural disturbances. He writes further: 
[...] many forests and grasslands depend on periodic natural fires to burn off dead vegetation, revitalise soil fertility, and emit seeds. A bird known as Kirtland's warbler nests only in recently burned forests. Likewise, numerous plants and animals have adapted to periodic flooding. Many plants germinate and absorb newly available dissolved nutrients mostly during a flood. Migratory birds also rely on a flood's bounty. As the ground slowly absorbs floodwaters, underground aquifers are refilled. Fish use the floodplain as a spawning ground and a nursery for their young, and some of the largest fish and crop harvests come the year after a flood. Having satiated the thirst of other creations through its disturbances, nature is endowed with a resilient mechanism to replenish human needs and maintain ecosystems. ${ }^{27}$

Environmental pollution has been identified as the major cause of climate change. The pollution spreads on water, land and air. Among the major polluters of nature are industry and energy which produce poisonous gases when fossil fuels like coal, gas and oil are burned. These fuels are also used by various means of transportation on land, water and air. Modern agricultural devices also constitute another serious threat to nature. Through these, natural terrestrial ecosystems are facing serious degradation consequent upon increases in the atmospheric concentrations of greenhouse gases. Others include toxic chemicals and gases, solid and hazardous wastes, travel and tourism, war and violence, smoking, drinking and drugs, population explosion and unethical acts. In his own case, Barau identifies deforestation, industrialisation, urbanisation, overpopulation and wars and conflicts as human factors of modern conception for environmental degradation. ${ }^{28}$

The extent of human interference with nature through encroachment is enormous and disastrous. Solihu refers to this as disasters by design, as industrialisation's intensified activities had exacerbated vulnerability in the twenty-first century. He further cites Janet Abramovitz's report of human induced flood caused by China's Yangtze River "which affected 223 million people, caused 4,000 deaths, damaged 61 million acres of cropland, and cost well over US\$ 36 billion." 29

Exercising a limitless exploitation of nature, man goes to the extent of encroaching on the rights of other beings that are constituents of nature. The big questions then are: why is it that man has decided to go to such an extent of exploiting the nature and what is the Islamic way out of this environmental threat in the name of climate change? The first question becomes pertinent in view of the fact that once the cause of a problem is identified, the solution to such a problem will not be farfetched.

A major factor behind excessive exploitation of nature by man is the spirit of materialism in him. The quest for material wealth seems universal, as nations are competing among themselves to attain recognisable economic status. They thus exploit the natural resources endowed them indiscriminately even beyond their needs forgetting that most of these resources are finite and non-renewable in nature. The materialistic tendency make them feel that they need more energy to develop 
their industries, that "they need more foreign exchange to develop their economic infrastructure and that they must take on huge debt repayments through their export earnings and finally, and a poor last, that they have to control the environment at heavy costs. ${ }^{30}$ The spirit of materialism in man metamorphosed to greediness and excessiveness whereby man obtains more than what he needs. It is on record that as at 1990, coal reserves were estimated at 534 billion tonnes and those of natural gas at 104 billion tonnes while oil reserves were estimated at 140 billion tonnes, an amount which can only last less than 100 years, while at the 1990 rate of consumption, coal would last for 200 years and gas for less than 150 years. ${ }^{31}$ With this, it is glaringly clear that climate change will become inevitable in the face of non-conservation of natural resources

Man tends to make the earth his paradise and therefore is unconcerned about the world beyond. He therefore wants every convenience for himself. He allocates to himself more than what he needs to the extent that his Creator asks him these rhetorical questions: "Do you build high palaces on every high place, while you do not live in them? And do you get for yourselves palaces (fine buildings) as if you will live therein forever?" (Qur'ān 26:128-129). One cannot however exhaust the reasons for man's decision to exploit nature unnecessarily, but the core point of it is the spirit of materialism in man which Ibn Raji sees as the bedrock of all evils. The next subheading answers the second question. ${ }^{32}$

\section{The Basis of Nature's Reaction to Human Exploitation through Climate Change}

Since the Qur'ān has explicitly confirmed the mutual interrelatedness and interdependence of mankind and other living organisms, it behoves mankind to understand that he has to mutually respect the rights of these creatures by not encroaching on the rights of other beings that are constituents of nature while exercising their duty as God's vicegerents. The Qur'ān confirms that all living creatures on earth are communities like that of mankind. By his actions and selfishness, man pollutes the environment, damages the land, water and atmosphere which are shared by other 'tenants'. So, plant life, birds, fishes and all species of living things are grossly affected by man's actions and attitudes. If mankind should therefore decide to tamper with other living communities unjustifiably, the reactions of such communities are therefore imminent at least in the interest of justice. This is because they are communities equally enjoining their provisions and sustenance from God. However, if these communities are powerless, one feels that their Creator may come to their aid even if He uses them against the wishes of mankind.

Closely related to the above is that mankind fails to understand that nature is not created only to be subservient to mankind, but as well to worship and adore 
God, the Creator. The Qur'ān confirms that "there is not a thing but celebrates His praise, but you understand not how they declare His glory" (17:44). Based on this view, exploitation amounts to the silencing of a whole class of God's worshippers by mankind who out of excessive materialism and maximisation of comfort on earth decides to explore nature, thereby disturbing the humble servants of God. So, if nature could supplicate that God should wage war against those who wage wars with them, one believes the prayer will be efficaciously answered by Him.

In the previous section, we expressed the well-defined and proportionate arrangement of nature beautifully put in place by God. Man's action seems to have altered the law, proportion and measure put in place by God. One lesson from this is that the divine arrangement is meant for the benefit of mankind and other creatures. However, because mankind wants everything good for himself, he greedily decides to alter the proportions of God. The implication of this is succinctly put by Muzammal Hussein who states that:

The consequences of this change, in proportion, has profound implications for the entire planet. Hence, within the discussion on climate change, from an Islamic perspective, the responsibility can be viewed to clearly rest on our collective shoulders, and within the natural world, the concept underpinning the current process taking place, is balance and proportion, which in terms of greenhouse gases gas been disturbed. ${ }^{33}$

Apart from the above, the interconnectivity of God's creation could be appreciated in climate change as its effect is global with no geographical boundary. It would therefore be short-sighted for one to feel unconcerned about environmental pollution of nature in any corner of the world. The Qur'ān enjoins one to be weary of fitnah which affects not in particular (only) those who do wrong (8:25). After all, the atomic accident of Chernobyl in Ukraine affected the health, food, vegetation, animal life, water and plant life of not only the (then) Soviet citizens, but also that of Western Europe and beyond. The effects of local wars in Chechnya, Angola, Afghanistan, Palestine, Iraq, Iran, Somalia, Kashmir and other places where the 'world powers' are exercising their might will undoubtedly have their toll on other nations as well. The oil fires and spills in the 1990/91 Gulf War did not only affect the environments, but also the neighbouring countries. ${ }^{34}$

That everything has been proportionately created by God is indicative of the fact that a single nation cannot be independent and self-sufficient. The land suitable for the rearing of animals may not be good for planting. There are many crops that are suitable for a particular type of land. What is not suitable for a particular land is surely suitable for another thing. In that wise, man is expected to understand that he does not need to force a particular plant not suitable for such a land by trying to change the nature of that land. Attempts to do so amount to depriving such a land of 
what is originally suitable for it. Cattle for instance are known for the production of milk and good sources of meat. An expectation to get such benefit from camels and horses may be disastrous as they are meant for the purpose of riding, carrying loads or drawing vehicles and not the production of milk. If now a horse is to be tamed to exclusively produce milk, its primary assignment will be jeopardised and this may not be good for society at large.

\section{Toward an Islamic Solution to the Problem of Climate Change}

The acknowledgement of trampling upon the rights of nature by man as the main cause of climate change gives a clue to observe that human transgression and selfishness need to be addressed if mankind is to experience peace with nature. The relationship between modern man and the environment is succinctly described by Seyyed Hossein Nasr as one between a man and a prostitute, the latter being treated by the former as a mere instrument of enjoyment. ${ }^{35} \mathrm{He}$ writes: "Rather than being like a married woman from whom a man benefits but also towards whom he is responsible, for modern man nature has become like a prostitute, to be benefited from without any sense of obligation and responsibility toward her."${ }^{\prime 36}$ In clear language, man should understand nature's rights over him. These rights could be attained if he desists from the misuse, mistreatment and destruction of natural objects.

In the first instance, man should make peace with himself by developing a sense of contentment and discouraging the spirit of excessive materialism in him that can make him restless. A man who is internally disturbed develops high blood pressure even if he works under an air conditioner. Apart from this, he makes peace with himself by avoiding substances that can harm him or affect his health. He should avoid smoking and taking drugs that can harm his body. This is important in view of the scientific findings on the evil effects of smoking not only on the smokers, but also on those around him. Furthermore, man is expected to maintain peace with other human beings. The incessant wars and violence among nations no doubt have caused serious damages to nature since both the victor and the vanquished bear their share of the consequences. The use of explosives, chemical weapons and other technological devices being used in modern times have serious devastating effects not only on the warring parties, but on other countries including other natural beings which have no reason to be affected.

One of the solutions offered by environmentalists for the problem of climate change is decarbonisation. This has however been considered not feasible by some scientists., in view of its serious adverse effect that such an attempt will have on export industries like mining, metal processing, agriculture and food processing, all of which are highly capital intensive. Giving a sarcastic response to decarbonisation, Ray Evans writes: 
The Environmentalist movement persists in denying the economic consequences of seriously attempted decarbonisation. In one particular sense they are theoretically correct. If we all do give up our motor cars and ride bicycles instead; if we were content to use electricity only when the wind was blowing; if we were prepared to give up the use of fertilisers and tractors, in effect if we were prepared to accept a standard of living similar to that of our forebears of the early nineteenth century, we could still be employed, although working at night would be difficult in the absence of electricity. ${ }^{37}$

As much as the above may sound funny and as much as it may not be possible to resort to the standard of our forebears, the use of fuel-free vehicles such as are common in China, India, Thailand and Bangladesh should be encouraged. It should be noted that because man wants every comfort for himself, he designs for himself too much fuel-consuming materials which consequently have adverse effects on him. Those in authority cannot afford to travel in one car, but need an entourage moving about in a fleet of cars. The spirit of maximisation of comfort blindfold them to realise that fuel consumption of these cars can be reduced if at most four people can travel in a car rather than encouraging the practice of one man one car. Man builds mansions at every nook and cranny of the world, whereas he cannot sleep in two rooms at a time, even less live in two houses at a time. We therefore submit that each nation should have adequate knowledge of the population of her citizens and so make adequate provision for them without wastage, while their exportations and importations should also be checked to not result in excesses. It is disheartening to observe that incorrect measures are taken to address the issue of climate change in some states particularly Osun State in Nigeria where cars and vehicles are compulsorily forced to pay for emission control. This to us is unnecessary extortion and exploitation of the public, whereas what is collected from them are not actually being spent for the purpose they are collected.

Furthermore, man should check a person's unrestricted freedom of exploring nature by using a particular constituent of nature for the purpose it was originally meant for. There is no doubt that each creation of God has a specific function it performs for mankind. If this is disrupted, its function is also affected.

Finally, Islam enjoins the conservation of resources apportioning great reward to planting of trees and discouraging indiscriminate felling of trees and bush burning. The Prophet was reported to have said "even if you fear that the world would end tomorrow, you should plant a tree (al-Bukhārī). He also condemned destruction of the habitat of wildlife and burning of ant-hills. Islam also frowns at wastage of natural resources and encourages cleanliness of environment. 


\section{Conclusion and Recommendations}

In this article, the case of man and his nature has been considered from the perspective of Islam. The verdict is that

- man is abusing the power of vicegerency conferred on him by God by unjustifiably transgressing set boundaries and by exploring deep into nature with no consideration for creation;

- the reaction of nature to its maltreatment by man in the form of climate change is therefore justifiable;

- as long as man refuses to allow other constituents of nature to have breathing space, the latter will continue to threaten human existence.

- man should reduce his spirit of excessive materialism and recognise other creatures of God in his dealings with nature. The world should therefore rise to the task of environmental pollution through limitless emission of gases and other toxic residues or else the innocents will equally share in the punishment of sinners.

- it is therefore a matter of religious and ethical duty to protect the environment; whosoever damages the environment must be proportionately punished by the appropriate authorities before nature takes it upon itself to punish the whole world for the sin of a few. In this manner, laws guarding the use of nature should be put in place and must be strictly implemented.

\section{Notes}

1. New Fact Sheet, "Facts about Climate Change," available online at http://www.thegreatwarming. com/pdf/climate change (accessed on 12 August 2010).

2. Ibid.

3. Adebayo and Abegunde Ogunlade (eds.), Environmental Law and Development (Ado-Ekiti [Nigeria]: Petoa Educational Publishers; 2007), 177-182.

4. Ray Evans, "Nine Facts about Climate Change," The Lavoisier Group, 2006, available online at http://www.lavoisier.com.au/articles/greenhouse (accessed on 23 July 2010), 2-6.

5. Ibid., 3-24.

6. Ibid

7. P. A. Ojebode, "The Mountainous Environment in the Bible: Its Implications for the Development of Christianity and Humanity," in: Gbola Aderibigbe and Deji Adegboyin (eds.), Religion and the Environment (Ibadan [Nigeria]: Olu-Akin Publishers and Nigerian Association for the Study of Religions and Education (NASRED), 2000), 131-133.

8. J. Omosade Awolalu and P. Adelumo Dopamu, West African Traditional Religion (Ibadan [Nigeria]: Onibonoje Press and Book Industries Ltd, 1979), 109.

9. Ibid.

10. Aliyu Salisu Barau, Environment and Sustainable Development in the Qur'an (Kano [Nigeria]: International Institute of Islamic Thought, Nigeria office, 2004), 10.

11. Ibid 
12. Ibid.

13. Ojebode, "The Mountainous Environment," 133-135.

14. Ibid.

15. See Qur'ān 2:30-34.

16. Imtiaz Ahmad, Historical Events of Makkah (Medina: Al-Rasheed Printers, 2006), 21.

17. Abdul Kabir Hussain Solihu, "Making Sense of Natural Disasters: An Islamic Hermeneutics of Malevolent Phenomena in Nature and Its Implication for Sustainable Development," American Journal of Islamic Social Science 24, no. 1 (2007), 58.

18. Ibid., 50 .

19. Akhtaruddin Ahmad (with Majid H.A. Hashim and Ghazi Al Hachim), Islam and the Environmental Crisis (London: Ta Ha Publishers Ltd, 1997), 115.

20. Harun Yahya, Wonders of God's Creation (London: Ta Ha Publishers, 2002), 20-21.

21. Ibid.

22. Abdullah Yusuf Ali, The Holy Qur'ān, English Translation of the Meanings and Commentary (Medina: The Custodian of the two Holy Mosques, King Fahd Complex for the Printing of the Holy Qur'ān, 1992), 980.

23. Yahya, Wonders, 91.

24. Solihu, "Making Sense," 65.

25. See http://www.thegreatwarming.com (accessed on 12 July 2010).

26. Solihu, "Making Sense," 51.

27. Ibid.

28. Barau, Environment, 13-15.

29. Solihu, "Making Sense," 59.

30. Ahmad et al., Islam, 93.

31. Ibid.

32. See Abdul Fattah Ibn Raji, Materialism as the Bedrock of all Evils (Lagos [Nigeria]: Islamic Study Circle, 1999), $1 \mathrm{ff}$.

33. Hussain Muzammal, "Islam and Climate Change: Perspective and Engagement" (2007), available online at http://lineonweb.org.uk/Resources/reading.htm (accessed on 25th July 2010), 12-13.

34. Ahmad et al., Islam, 92-93.

35. Seyyed Hossein Nasr, Man and Nature (Kuala Lumpur: Foundation for Traditional Studies, 1986), 13-14.

36. Ibid.

37. Evans, "Nine Facts," 22. 